\title{
Autobiograficzny film dokumentalny. Eksplikacja autorska filmu Self(less)-Portrait[1]
}

Już na początku studiów w łódzkiej Szkole Filmowej zaskoczyła mnie pewna rzecz. Na Wydziale Reżyserii, na którym studiowałem, na każdym roku musieliśmy zrealizować dwie etiudy: jedną fabularną i jedną dokumentalną. Przeraziłem się - zupełnie nie interesował mnie film dokumentalny. Przynajmniej nie w tej formie, w jakiej go znałem. Można powiedzieć, że przed przyjazdem do Łodzi byłem ignorantem w tej dziedzinie. Kiedy myślałem o filmie dokumentalnym, miałem przed oczami ślizgające się pingwiny na Antarktydzie i chowające się w krzakach tygrysy, czyhające na zdobycz w gorącej Afryce. Szybko zrozumiałem, że Polska Szkoła Dokumentu jest czymś zupełnie innym. Nie sposób wymienić wszystkich tytułów, które zrobiły na mnie ogromne wrażenie: Pierwsza miłość Krzysztofa Kieślowskiego, Rok Franka W. Kazimierza Karabasza, Jak żyć Marcela Łozińskiego, Pożar! Pożar! Coś nareszcie dzieje się... Marka Piwowskiego i wiele, wiele innych. Dzięki nim odkryłem wcześniej nieznaną mi formę filmu, ale w dalszym ciągu patrzyłem na to $\mathrm{z}$ boku, a ćwiczenia dokumentalne realizowałem jedynie jako obowiązkową część studiów, ponieważ mój świat kręcił się wokół filmu fabularnego.

Trudno wyjaśnić, dlaczego filmowiec wybiera drogę filmu dokumentalnego lub filmu fabularnego. Myślę, że najprostszą odpowiedzią na pytanie o powód mojej ucieczki od dokumentu może być lęk przed ludźmi. Bardzo dobrze pamiętam pierwsze ćwiczenie na zajęciach profesor Doroty Kędzielawskiej. Zadanie było z pozoru proste: znaleźć bohatera i przeprowadzić z nim wywiad. Nie zapomnę, jaki to był dla mnie koszmar. Znalazłem mężczyznę - informatyka - który pracował w firmie komputerowej na ulicy Targowej, tuż obok szkoły. Nie znałem go wcześniej i do realizacji ćwiczenia nic o nim nie wiedziałem. W dniu wywiadu poszedłem do jego firmy i powiedziałem, że czas już kręcić. Zauważyłem, że informatyk bardzo się stresuje i najchętniej wycofałby się z całego przedsięwzięcia. Miał powody, ponieważ ja - twórca - praktycznie nic mu przed realizacją nie wytłumaczyłem. Najgorsze było to, że czułem się tak samo jak on. Wywiad był koszmarny. Nie chciałem mieć nigdy więcej nic wspólnego ze światem rzeczywistym jako materią filmu niefikcjonalnego.

Moje nastawienie do filmu dokumentalnego zaczęło się powoli zmieniać dopiero po realizacji drugiej szkolnej etiudy dokumental-

[1] Zredagowane fragmenty pracy magisterskiej napisanej pod opieką prof. dr. hab. Andrzeja Sapiji
Images

vol. XV/no. 24

Poznań 2014

ISSN 1731-450X
Dlaczego o filmie autobiograficznym? w PWSFTviT w Łodzi. Praca dostępna w Bibliotece PWSFTviT w Łodzi, sygn. D 2414. 
nej Tam, gdzie słońce się nie spieszy (2009) pod opieką artystyczną Macieja Drygasa i Mirosława Dębińskiego. Przede wszystkim muszę przyznać, że praca nad nim sprawiła mi wielką przyjemność. Na planie znajdowałem się tylko ja, operator, kierownik produkcji i mieszkańcy spokojnej wioski w słowackich górach. Film składa się wyłącznie z codziennych obserwacji zwyczajnego życia. Skłamałbym, gdybym powiedział, że wioska w rzeczywistości wygląda tak, jak w moim filmie. Pokazałem ją w taki sposób, w jaki ja ją widziałem. W tym filmie po raz pierwszy pojawia się fascynujący mnie do dziś temat śmierci. $\mathrm{Na}$ ekranie obserwujemy ludzi, którzy mają niewiele do roboty i właściwie całe dnie czekają tylko na śmierć, która w końcu przychodzi. Nie oznacza to, że tak w rzeczywistości jest, ale wyłącznie ta część tego świata mnie interesowała i o niej chciałem zrobić film. Montując materiał, zrozumiałem, że udało mi się opowiedzieć o śmierci w taki sposób, w jaki bym tego nie potrafil zrobić w filmie fabularnym przekonujący i czysty. Zobaczyłem, że można opowiedzieć własną historię przez prawdziwy świat. To zmieniło mój punkt widzenia na film dokumentalny.

Podczas pracy nad Tam, gdzie słońce się nie spieszy nurtowało mnie pytanie, jak widz zniesie film, w którym brakuje wyrazistej fabuły i dramaturgii. Dokument trwał osiemnaście minut i to wystarczyło. Etiuda została dobrze odebrana, zebrała pozytywne recenzje, była nagradzana na festiwalach filmowych. Kiedy jednak zobaczyli ją ludzie niezwiązani ze światem filmowym, brak dramaturgii okazał się źródłem nieporozumień dotyczących podstawowej kwestii: o czym właściwie jest ten film? Broniłem się, że przecież to film o śmierci. Ale kogo dzisiaj interesuje śmierć opowiedziana w sposób tak nudny, jak w twojej etiudzie? - słyszałem w odpowiedzi. Zrozumiałem, że będąc ambitnym filmowcem, owszem, muszę starać się robić filmy głębokie, lecz jednocześnie nie mogę zapominać o widzach. Trzeba było znaleźć kompromis.

Moje nastawienie do filmu dokumentalnego po raz kolejny zmieniła praca nad ostatnią, dyplomową etiudą dokumentalną Self(less)-Portrait[2] (2012), która powstała w łódzkiej Szkole Filmowej pod opieką profesora Kazimierza Karabasza. Po upływie dwóch lat od momentu rozpoczęcia zdjęć uważam, że początki stanowiły eksperyment bez głębszej myśli. Zanim jednak opowiem o filmie, muszę wspomnieć o moim lęku wysokości, który był pośrednim bodźcem do powstania filmu. Pomimo tej przypadłości zdecydowałem się jakiś czas temu na długi lot do Nowego Jorku. Samolot wystartował, a ja sobie uświadomiłem, że mój strach jest większy niż myślałem. W plecaku miałem małą kamerę cyfrową. Zacząłem przeglądać zarejestrowane w niej różne materiały, tylko po to, żeby myśleć o czymkolwiek innym niż o samolocie. W pewnym momencie zacząłem obserwować świat wokoło mnie

[2] Na łamach pisma „Images” ukazało się obszerne omówienie tego filmu: K. Mąka-Malatyńska, Nostalgiczny uśmiech. Autobiograficzny film Mateja Bobrika
„Self(less) Portrait”, „Images” 2012, nr 20 (vol. XI), s. 153-162. 
przez monitor LCD. Okazało się, że miało to na mnie bardzo dobry, uspokajający wpływ. Jakby świat, który widziałem przez kamerę, nie był prawdziwy i to, co się działo, było tylko filmem. Kamera uratowała mnie przed paniką.

Historię z samolotu przypomniałem sobie pewnego wieczora w listopadzie 2010 roku, kiedy moje życie na jakiś czas zostało zaburzone po nagłej śmierci mojej matki. Odruchowo wziąłem tę samą kamerkę i zacząłem filmować. Świat widziany przez nią wydał mi się bardziej bajką niż rzeczywistością, jakbym patrzył przez różowe okulary, stawał się taki, jaki go wykreowałem. Tak rozpocząłem realizację filmu Self(less)-Portrait - kompletnie bez koncepcji i konkretnego pomysłu. Szybko jednak obudził się we mnie instynkt filmowca, ponieważ zacząłem kontrolować sytuację. Stopniowo w mojej głowie układał się plan, w jakim kierunku ma zmierzać projekt. Po dwóch latach powstał czterdziestopięciominutowy film, który sam reżyserowałem, kręciłem, zmontowałem i w którym występowałem. Otrzymałem wielkie wsparcie od profesora Kazimierza Karabasza, który od samego początku uważał projekt za interesujący.

Film opowiada o moim życiu i o tym, jak zmieniło się ono na skutek trudnych doświadczeń. Kamerę kieruję na siebie i moją rodzinę. Mozaika, która powstała $\mathrm{z}$ bardzo osobistych fragmentów życia, pokazuje moją relację z dwiema najbliższymi kobietami: samotną babcią, z którą utrzymywałem kontakt wyłącznie przez telefon, i Mariko, moją japońską dziewczyną, z którą decydujemy się wziąć ślub. Film pokazuje nasze codzienne życie, koncentrując się na prozaicznych szczegółach, dzięki którym widz odkrywa mój świat emocjonalny. Doświadczenie, które zyskałem przy pracy nad tym filmem, jest ogromne, przede wszystkim na etapie montażu. Po przełamaniu pierwszego lęku związanego $\mathrm{z}$ oglądaniem samego siebie na ekranie, patrzeniem na siebie i na moją małżonkę jak na obcych ludzi, pojawiły się podstawowe pytania: po co robię film o sobie? Dlaczego wymagam od widza, żeby się interesował moim życiem? Lęk wyrażony w tych pytaniach zmusił mnie do myślenia o filmie nie tylko jako o pewnej historii, choć to dla mnie bardzo ważne, ale również jako o przekazie skierowanym do konkretnych widzów. Nieustannie zastanawiałem się nad tym, jak udowodnić im, że powstanie tego filmu miało sens.

Po raz pierwszy, realizując film, myślałem tyle o odbiorcy, o przystępności opowiadania i o tym, jak utrzymać zainteresowanie przez czterdzieści pięć minut. Była to ogromna odpowiedzialność, ale niezwykle ekscytująca. Mam świadomość, jak wiele ma słabych punktów. Przede wszystkim należą do nich: niska jakość obrazu i nieestetyczne zdjęcia. Film robi wrażenie utworu zrealizowanego przez amatorów. $Z$ drugiej strony - udało mi się ukierunkować emocje widzów, a jest to z pewnością coś, co odróżnia moją dyplomową etiudę od zwykłego home video. Temat filmu - śmierć - został ukazany z perspektywy młodych ludzi, poprzez codzienność, z którą wielu może się identyfikować. Pewności 


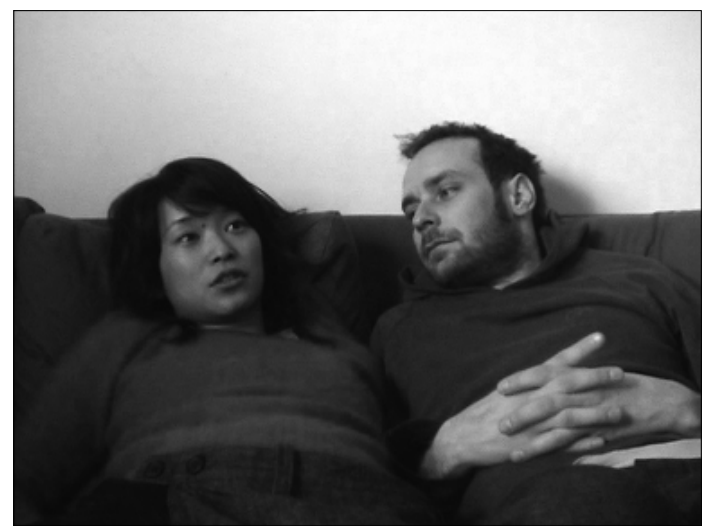

co do kształtu i sensu tego przedsięwzięcia nabrałem dopiero $\mathrm{w}$ momencie, kiedy film pokazałem widzom niezwiązanym $\mathrm{z}$ branżą filmową i odbiór był pozytywny. Usłyszałem, że obejrzeli film, a nie szkolną etiudę.

Self(less)-Portrait wprawdzie jest filmem, ale dla mnie był to bardziej eksperyment, z którego dopiero później powstał film. Rozpoczynając realizację, nie wiedziałem, jak bogata jest historia kina autobiograficznego. Na rozwój tego nurtu wpłynęła z pewnością rewolucja technologiczna, która zmieniła całe kino, a w szczególności kino dokumen-

Kadr z filmu dokumentalnego Self(less) Portrait, Matej Bobrik, prod. PWSFTviT w Łodzi, 2012

\section{Autorskość podstawą autobiograficznego filmu dokumentalnego} talne. Metamorfozie uległ sposób opowiadania, poszerzył się wachlarz tematów, widz przybliżył się do bohatera. Wielokrotnie wzrosła produkcja filmowa, zwiększyła się także liczba filmów autobiograficznych, których koszty produkcji mogą być bardzo niskie.

Co oznacza określenie „autorski”? W filmie fabularnym kino autorskie jest to kino charakterystyczne dla poszczególnych twórców, będące wyrazem ich indywidualnego stylu i wizji artystycznej. Reżyser zazwyczaj jest związany $z$ filmem od powstania scenariusza aż do etapu montażu. Tematyka porusza problemy egzystencjalne, skupia się na krytycznej wizji świata. Pojęcie „kino autorskie” bywa często zamiennie stosowane $\mathrm{z}$ terminem „kino artystyczne”. Przeciwstawianie go filmowym produkcjom rozrywkowym stało się z czasem wartościujące i nieprecyzyjne.

Istotą kina autorskiego jest wolność twórcy rozpoczynająca się od chwili wyboru tematu i sposobu podejścia do niego. Takie stwierdzenie może wydawać się oczywiste, ale, niestety, w praktyce zachowanie tej wolności nie jest takie proste, ponieważ w formę filmu często ingeruje producent - zamawiając film, niekiedy stara się kierować projektem według własnych potrzeb. Autorski film może pozostać autorski tylko wtedy, kiedy autor będzie chroniony przed taką ingerencją. Aby jej uniknąć, wielu reżyserów zakłada własną firmę, co daje im możliwość bycia producentami swoich utworów.

Termin „kino autorskie” powstał pod koniec lat pięćdziesiątych, kiedy do głosu w kinie europejskim dochodzili twórcy francuskiej Nowej Fali. W tym czasie we Francji tworzyła się silna grupa reżyserów, takich jak Jean-Luc Godard, François Truffaut, Claude Chabrol i Jacques Rivette. Wówczas byli oni jeszcze krytykami filmowymi czasopisma „Cahiers du Cinéma”. W tym kręgu zrodziła się maksyma: „Nie ma dzieł, są tylko autorzy". Według nich autorem filmu jest reżyser, którego styl odbija się mocno w każdym filmie, zawsze obecny i rozpoznawalny. Od czasów rewolucji nowofalowej fenomen kina autorskiego wiązany jest zwykle $\mathrm{z}$ kinem europejskim, a tym samym przeciwstawiany kinu amerykańskiemu jako poddanemu prymatowi gatunku. Historycy kina 
uznają okres lat pięćdziesiątych i sześćdziesiątych za epokę wielkich autorów. Jest to czas, kiedy w kinie europejskim pojawili się Ingmar Bergman, Michelangelo Antonioni i Federico Fellini.

Uważam, że mimo wszystko w filmie fabularnym trudno mieć zupełną wolność twórczą, ponieważ proces jego realizacji jest związany nie tylko $\mathrm{z}$ ogromnym budżetem, ale również $\mathrm{z}$ mnóstwem ludzi pracujących w ekipie. Reżyser współpracuje niemal zawsze z operatorem, scenografem, kostiumografem, aktorami itd. Każdy z nich daje coś swojego, twórczego, i w ten sposób film staje się w pewnym sensie dziełem zbiorowym.

W filmie dokumentalnym panuje o wiele większa wolność. Dzięki współczesnej technologii ekipa filmowa może zostać zredukowana do jednej osoby - samego reżysera. Co oznacza „autorski film” w dokumencie? Zdecydowałem się porównać mój punkt widzenia $\mathrm{z}$ bardziej doświadczonymi reżyserami filmów dokumentalnych. Przeprowadziłem wywiady z dwoma polskimi dokumentalistami: Pawłem Łozińskim i Jackiem Bławutem. Nasza rozmowa zaczęła się kluczowym dla mojej pracy pytaniem: co, ich zdaniem, kryje się pod hasłem „film autorski”?

Według Pawła Łozińskiego w polskiej tradycji dokumentalnej pojęcia filmu autorskiego i filmu dokumentalnego są tożsame, a przekaz niefikcjonalny, który nie jest autorski, to po prostu reportaż:

Nie ma jednej definicji, podejrzewam, że każdy reżyser widzi to trochę inaczej. „Autorski” oznacza, że to jest coś więcej niż tylko zwykła relacja $\mathrm{z}$ wydarzenia, reporterski zapis czy news pokazujący jeden do jednego, że „coś jest” albo „coś się wydarzyło”. „Autorski” oznacza dla mnie, że reżyser ma mi coś do powiedzenia, wciąga mnie w swój świat, pokazuje, jak go widzi. Idzie w głąb swojej historii, dociera blisko bohaterów. Chce, żebym poczuł, przeżył czy pomyślał to, co on. Czymś chce się ze mną podzielić, właśnie jakąśs myślą albo uczuciem[3].

Reżyser Jacek Bławut za podstawę autorskiego kina dokumentalnego uważa przede wszystkim samotność autora:

Dokumentalista musi być samotny jak prawdziwy artysta - malarz czy muzyk. Tylko w samotności powstają najwspanialsze rzeczy. Często zdarzały mi się sytuacje, że na planie byłem zupełnie sam. Nie miałem operatora, nie miałem dźwiękowca. Wtedy stwarza się niezwykła intymność, jesteś niesamowicie związany z bohaterem. Jest większa koncentracja i warunki zmuszają do prawdziwego tworzenia. Najważniejsze, żeby poczuć, kto do ciebie mówi i jakie emocje na ciebie przenosi. Filmowiec musi się oddać filmowi. Musi coś dać z siebie, inaczej nic z powrotem nie dostaje[4].

Według Jacka Bławuta w dokumentalnym kinie autorskim równie ważny jest etap montażu, kiedy reżyser ma możliwość montowania według swoich potrzeb, bez oglądania się na potrzeby producentów lub widza: 
W montażowni siedzę z filmem nieraz pół roku, rok, nawet więcej. Oczywiście zawsze montuję z montażystą, ale nigdy nie dopuściłem do sytuacji, żebym zostawił montażystę samego w montażowni. Uważam, że w dokumencie to jest niemożliwe. Tym bardziej, że montaż to najprzyjemniejsza część pracy nad filmem. Wtedy to jest moje, osobiste, wtedy czuć moje emocje. W filmie autorskim musi być przede wszystkim zadowolony reżyser, bez żadnych ograniczeń zewnętrznych[5].

Moim zdaniem $\mathrm{w}$ dokumencie $\mathrm{z}$ kinem autorskim mamy naprawdę do czynienia wtedy, kiedy czujemy autora filmu za kamerą lub nawet przed nią. Nie ma sposobu, by bardziej zbliżyć się do historii niż wówczas, gdy twórca sam aktywnie w niej uczestniczy. Kiedy autor jest emocjonalnie związany $\mathrm{z}$ bohaterami, istnieje wielkie prawdopodobieństwo, że będzie w stanie nawiązać z nimi intymniejszą relację i dzięki temu opowie widzowi historię naprawdę od środka. Dlatego też skupię się na kinie autorskim dokumentalnym, w którym autor jest jednocześnie bohaterem filmu lub jego obecność za kamerą jest na tyle mocna, że staje się jego tematem.

Bohater za i przed kamerą
W filmach autobiograficznych autor wykorzystuje formę dokumentalną do analizy własnego życia, jakiegoś trapiącego go problemu lub nietypowej sytuacji, w której się znalazł. Kamera jest narzędziem, które umożliwia dokonywanie odkryć. Zazwyczaj ta forma dokumentu sytuuje się na granicy home video, co często pomaga autorowi w stworzeniu filmu bardziej intymnego, a to z kolei pomaga widzowi wejść $\mathrm{w}$ świat autora i identyfikować się z jego problemem. Dokumenty autobiograficzne są zwykle filmowane małą ręczną kamerą. Kiedyś do tego była używana kamera $16 \mathrm{~mm}$, dzisiaj zwykły handycam cyfrowy.

Kim są właściwie ci „dziwacy”, którzy decydują się odwrócić kamerę na samych siebie? Według Jima Lane, amerykańskiego pisarza, autorami filmów autobiograficznych zazwyczaj nie są ludzie dobrze znani szerokiej publiczności. Nie są to artyści z uznanym dorobkiem, którzy mogliby w filmie korzystać ze swojej sławy. Zazwyczaj to filmowcy, którzy film robią bez pieniędzy, w skromnych warunkach i bardziej skupiają się na konkretnym etapie w swoim życiu niż na tym, kim są. Pokazują swoje codzienne życie, rozmowy z bliskimi, a zdjęcia często odbywają się w ich domu. Często oprócz tego, że występują i są reżyserami, zajmują również miejsce za kamerą i później w montażowni[6].

Filmy autobiograficzne można podzielić na trzy główne grupy. Twórcami pierwszej z nich są ludzie dotknięci bardzo ciężką chorobą zazwyczaj to AIDS, alzheimer, bulimia, choroby psychiczne, rak. Drugą grupę tworzą dzieła autorów przeżywających dramat rodzinny - śmierć bliskiej osoby, relacja ojciec-syn czy skomplikowany układ partnerski. Ostatnia grupa to filmy o kryzysie osobistym - związanym z religią czy też poszukiwaniem swojej tożsamości.
[5] Ibidem.

[6] Por. J. Lane, The Autobiographical Documentary in
America, University of Wisconsin Press, Wisconsin 2002. 
Trudno określić i kategoryzować, jakie są powody, które doprowadzają autorów do filmowania samych siebie. Jakie są ich cele, jeżeli w ogóle przy pierwszym włączeniu kamery jakieś mają. Dla niektórych jest to z pewnością forma terapii, możliwość podzielenia się z kimś swoimi problemami. Jest to fenomen, który się coraz częściej przejawia nie tylko $\mathrm{w}$ filmie dokumentalnym, ale $\mathrm{w}$ Internecie $\mathrm{w}$ formie wideoblogów. Zazwyczaj młodzi ludzie robią tak zwane videodiary, w których na stronach internetowych dzielą się ze światem swoimi codziennymi problemami. Najbardziej popularne są dwa portale: YouTube i MySpace. Dzięki wideoblogom autorzy zyskują pewne poczucie bezpieczeństwa: nie są sami ze swymi problemami i mają gdzieś tam, po „drugiej stronie”, kogoś bliskiego, z kim mogą się swoim utrapieniem podzielić. Popularność takiej formy jest z pewnością konsekwencją swoistego eskapizmu: wolimy opowiadać o naszych kłopotach, mieć odbiorców, którzy nas wysłuchają, niż rzeczywiście konfrontować się z problemami i próbować znaleźć rozwiązanie. Innymi słowy, wolimy się wygadać, niekoniecznie oczekując jakiejś reakcji zwrotnej.

W 2009 roku powstał film Twenty Show: Le Film (reż. Godefroy Fouray, François Vautier), złożony wyłącznie z wideoblogów. Jest to portret zbiorowy dwudziestoletnich Francuzów, którzy prezentują samych siebie przez sieć społecznościową MySpace. Dzięki ich dziennikom internetowym widz poznaje młodzież $\mathrm{z}$ różnych warstw francuskiego społeczeństwa. Dowiadujemy się, jakie uczucia towarzyszą bohaterom w codziennym życiu - stres w szkole, pierwsza miłość, pierwsze doświadczenie $\mathrm{w}$ zawodzie, imprezy $\mathrm{z}$ kolegami, samotność i nuda. Bez wątpienia siła filmu polega na skoncentrowaniu się na wirtualnej rzeczywistości Internetu. Paradoksalnie wyłącznie wirtualny kontakt bohaterów-autorów ze światem sprawia, że autor pozostaje niedookreślony, a punkt widzenia zatarty.

Celem wielu autorów filmów autobiograficznych jest ukazanie problemów o zasięgu globalnym, nie tylko osobistym. Takim przykładem jest film Petera Friedmana i Toma Joslina Silverlake Life: The View from Here (1993). Po tym, jak Mark Massi w 1989 roku dowiaduje się, że jest chory na AIDS, jego partner życiowy, reżyser i wykładowca, Tom Joslin, decyduje się na kręcenie filmu dokumentalnego o nim. Kiedy sam reżyser również zachoruje na AIDS, film staje się zapisem codziennej miłości dwóch mężczyzn noszących w sobie śmiertelną chorobę. Jesteśmy z nimi w domu, przyglądamy się ich dniom powszednim, patrzymy, jak się sobą nawzajem opiekują, wychodzimy z nimi na codzienne spacery do parku i na zakupy do sklepu. Jesteśmy świadkami wielkiej miłości dwóch mężczyzn. Po śmierci Toma Jaslina Massi decyduje się kontynuować realizację filmu. Przez filtr jego wrażliwości doświadczamy śmierci ukochanego partnera, pogrzebu, a później kremacji. Kiedy Massi rok później umiera, zmontowania filmu podejmuje się Peter Friedman, student Toma Jaslina. Obaj mężczyźni umarli w wieku czterdziestu trzech lat. Bohaterowie nie prezentują żadnych politycznych poglądów, film jest przede wszystkim opowieścią 
o umierających ludziach, a jednak otwiera widza na istotne socjologiczne, medyczne i polityczne konteksty. Obraz choroby jest w nim bardzo odległy od tego, jaki w momencie realizacji dominował w świadomości społecznej. W swojej wymowie zaprzecza powszechnemu wówczas przekonaniu, że jest to choroba dotykająca wyłącznie ludzi, którzy prowadzą nieuregulowane życie seksualne, często zmieniają partnerów i zgodnie $\mathrm{z}$ obowiązującymi $\mathrm{w}$ tamtych czasach poglądami $\mathrm{w}$ gruncie rzeczy zasługują na karę, jaką jest ta śmiertelna choroba. W Silverlake Life relacja dwóch mężczyzn pokazana została jako pełen pięknej miłości czysty związek ludzi, którzy pomagają sobie w najtrudniejszym momencie ich życia, rozbijając tym samym wszystkie bariery moralne.

Niezależnie od tego, kto decyduje się na zrobienie dokumentu autobiograficznego i z jakiego powodu podejmuje tę decyzję, niemal zawsze powstaje kino niezwykle osobiste, które przybliża świat jego autora bardziej niż jakikolwiek inny rodzaj filmu. Autentyczność jest esencją tego rodzaju obrazów i wszystkie niedoskonałości techniczne lub dramaturgiczne są w tych przypadkach wybaczalne. Najważniejsza pozostaje bowiem ich treść i przekaz.

Korzenie filmu autobiograficznego
Filmy autobiograficzne były i w znacznym stopniu w dalszym ciągu pozostają pod wpływem klasycznych stylów dokumentalnych. Są zazwyczaj kręcone z ręki, bez ekipy filmowej. Narodziny tego stylu związane są $\mathrm{z}$ ruchem direct cinema, który wpływał na kino dokumentalne i fabularne od początku lat sześćdziesiątych. Za film przełomowy uważany jest dokument Richarda Leacocka Primary (1960). Jego autor przygląda się wyborom prezydenckim w Stanach Zjednoczonych, kiedy o wybór na kandydata Partii Demokratycznej walczyli John F. Kennedy i Hubert Humphrey. Kamera z ręki oraz lekki sprzęt dźwiękowy umożliwiły filmowcom łatwe poruszanie się i śledzenie kandydatów wszędzie gdzie byli, a tym samym dawały możliwość uchwycenia ich emocji. Direct cinema to nie tylko mobilna kamera i synchroniczna rejestracja dźwięku. Jego istota polegała na dyskretnej obecności ekipy filmowej, głównym celem reżyserów było bowiem ograniczenie ingerencji do minimum, tak by uzyskać efekt ekranowej prawdy. Związek filmu autobiograficznego $\mathrm{z}$ direct cinema polega przede wszystkim na podobnym sposobie realizacji wielu $\mathrm{z}$ autodokumentów: mała ekipa, kamera z ręki. Jednocześnie jednak zasadnicza różnica pomiędzy tym nurtem a dokumentem autobiograficznym polega na bardzo silnej ingerencji w świat przed kamerą w przypadku tego drugiego. W filmach autobiograficznych nie da się owego wpływu uniknąć, bo jest ona konieczna i stanowi podstawę filmu.

W tym samym czasie, kiedy w Stanach Zjednoczonych rozwijał się direct cinema, we Francji dokumentaliści zapoczątkowali cinéma vérité. Początkowo było ono porównywane do ruchu amerykańskiego, francuski kierunek był bowiem również kojarzony z kamerą z ręki i lekkim sprzętem dźwiękowym, który umożliwiał reżyserom swobodniejsze poruszanie się i tym samym przebywanie bliżej bohaterów. Jednak 
francuscy reżyserzy uważali, że wywiad, sonda, które odrzucali twórcy direct cinema, nie osłabiają dokumentalnej wartości filmu - środki te uznawali za formę prowokacji, sposób na poruszanie niewygodnych tematów, a tym samym umieszczanie bohatera w sytuacjach niewygodnych, w których reakcje były, ich zdaniem, zawsze prawdziwe.

Zagadnienia te porusza w swoim do pewnego stopnia autotematycznym filmie Kronika jednego lata (1960) Jean Rouch. Opowiada o francuskiej klasie robotniczej i stara się dociec, czy bohaterowie są zadowoleni z życia. Jean Rouch w swoim filmowym eksperymencie chciał odpowiedzieć na pytanie, czy ingerencja reżysera w filmie dokumentalnym rzeczywiście odbiera prawdziwość wypowiedzi. Wraz z socjologiem Edgarem Morinem zdecydowali się usiąść przed kamerą i porozmawiać ze swoimi bohaterami. Film otwierają obserwacyjne ujęcia budzącego się Paryża. Ludzie wychodzą z domów i zmierzają do pracy, większość do dużych fabryk. Autorskie intencje od początku wyjaśnia widzowi głos reżysera $\mathrm{z}$ offu: „W tym filmie, zrobionym bez aktorów, pokażemy życie mężczyzn i kobiet, którzy poświęcili czas dla filmu i eksperymentu, którego celem jest prawda”. Następnie widzimy Jeana Roucha i Edgara Morina siedzących przy stole $\mathrm{z}$ jedną $\mathrm{z}$ bohaterek, Marceline. Sposób realizacji filmu jest również przedmiotem rozmów twórców:

Jean Rouch: Wiesz co, Morin, uważam, że rozmowa przy okragłym stole to świetny pomyst. Zastanawiam się, czy to możliwe, by nakręcić naturalna rozmowe przy włączonej kamerze. Na przykład $z$ Marcelina, czy można porozmawiać spokojnie i swobodnie?

Edgar Morin: Z Marcelina można spróbować.

Marcelina: To nie będzie łatwe.

Jean Rouch: Dlaczego?

Marcelina: Czuję się zestresowana.

Jean Rouch: Zestresowana? Czym?

Marcelina: Zestresowana, bo nie mogę uniknąć tej sytuacji.

Jean Rouch: Morin i ja chcemy tylko, żebyś odpowiedziała na kilka pytań. Wszystko, na co się nie zgodzisz, może być później wyrzucone w montażu. Dobrze?

Edgar Morin: Nie masz żadnego pojęcia o pytaniach. Właściwie my też nie. To, co chcemy osiagnąć, to film o tym, jak ludzie żyją. Ty jesteś naszym pierwszym bohaterem. Opowiedz nam, jak żyjesz. Na poczatek opowiedz, jak wygląa twój dzień.

Po rozmowie z Marceliną, w której bohaterka opowiada o swoim codziennym życiu, reżyser pyta ją, czy mogłaby razem z nimi przejść się ulicami Paryża, zaczepiać przypadkowych ludzi i prosić ich o odpowiedź na proste pytanie: „Czy jesteś szczęśliwy?”. Marcelina zgadza się. Spotykamy kolejnych bohaterów, którzy opowiadają o swoim losie i swojej codzienności. Widz w pewnym momencie zupełnie 
zapomina o tym, jak film się rozpoczął i że bardziej niż o film chodzi o eksperyment. Skupia się na ciekawych i wzruszających opowieściach. Dopiero pod koniec filmu reżyser przypomina, że mieliśmy do czynienia przede wszystkim z eksperymentem. Wszyscy bohaterowie znajdują się w sali kinowej i oglądają zmontowany film. Niektórzy z nich uznają go za fałszywy, zagrany. Jeszcze inni są pod wrażeniem prawdziwości wypowiedzi. Po intensywnej dyskusji z bohaterami Jean Rouch i Edgar Morin, już prywatnie, ale przed kamerą, podsumują projekt:

Edgar Morin: Jak się czujesz po projekcji?

Jean Rouch: Było to bardzo ciekawe. Bohaterowie podzielili się na dwie grupy. Jedni uważali, że ich filmowy obraz jest nieprawdziwy. Inni uważali, że udało nam sie pokazać prawdziwe fragmenty ich życia. Co to oznacza? Uważam, że osiagnęliśmy prawdę, która jednak nie jest prawdą codzienną. [...]

Edgar Morin: Nie wiadomo, oni sami nie sa pewni. Marcelina na projekcji mówiła, że w niektórych scenach zagrała.

Jean Rouch: Ja uważam, że nie zagrała. A jeżeli tak, to pokazało to jej prawdziwa twarz. Ten film, w przeciwieństwie do zwykłego filmu, pokazał nam życie. Ludzie reagowali tak, jak reagują na co dzień. Bohaterowie i widzowie nie byli kierowani. Nie decydowaliśmy, czy ten czy inny bohater jest dobry, mądry, czy ładny. W ten sposób widz poznał osoby i ich historie, $z$ których niektóre byly na tyle intymne, że może w ogóle nie chciałby ich poznawać. Niektórych to wzruszało, innych nie. Czyli uważam, że nasz projekt nie jest zupetnie nieudany.

Edgar Morin: A ty się wzruszyłeś?

Jean Rouch: Widziałem ten film tyle razy, że straciłem dystans. Ale tak, nadal mnie bardzo wzrusza. Ale w inny sposób. Przede wszystkim, myślałem, że wszystkich będzie ten film wzruszał. Teraz widzę ludzi, którzy krytykuja niektórych moich bohaterów. Miałem nadzieję, że widz pokocha ludzi, których ja lubię. Chcieliśmy zrobić film o miłości i okazało się, że widzowie moich bohaterów nie kochają. Ale taka jest nasza praca, musimy przez to przejść. Chyba mamy problem.

Po tej rozmowie autorzy filmu żegnają się i każdy idzie swoją drogą. Widzimy niezadowolonego Jeana Roucha i w tle słychać pytanie Marceliny z początku filmu - „Jesteś szczęśliwy?”.

Nawet jeżeli twórcy zostawiają widza $\mathrm{z}$ wrażeniem, że nie udało im się zrobić prawdziwego filmu dokumentalnego, ja, jako widz, uważam Kronikę za dokument wybitny, w którym udało się uchwycić życie człowieka. Odnajduję w nim również pewne sygnały filmowego autobiografizmu, kiedy na przykład autorzy, prowadząc widza przez film, sami siebie czynią bohaterami, którzy na początku filmu przedstawiają problem i cele, a na samym końcu konfrontują się z efektem.

Wpływ direct cinema na dokument autobiograficzny polega przede wszystkim na użyciu kamery z ręki i minimalizowaniu ekipy, zaś wpływ cinéma vérité na wprowadzeniu do kina niefikcjonalnego autorefleksji i otwartego sposobu analizowania problemów artystycznych. 
Wydaje się, że dziś posiadanie kamery cyfrowej i kręcenie nią filmów nie stanowi właściwie żadnego problemu. Ta możliwość zmieniła sposób myślenia w kinie i o kinie, a w szczególności wpłynęła na film dokumentalny, w którym możliwość kręcenia na małych kamerach z nieograniczoną ilością materiału stała się ogromnym dobrodziejstwem.

Zastanawiam się, czy zacząłbym kręcić film Self(less)-Portrait, gdyby nie współczesna technologia, dostępność sprzętu. Myślę, że mój film powstał właśnie dzięki tej technologicznej rewolucji. Pewnie podobnie było z wieloma innymi współczesnymi dokumentami autobiograficznymi. Małe i tanie kamery mogą zrobić reżysera z niemal każdego człowieka. Wydaje się, że wystarczą tylko dobre chęci i pasja do kina. Coraz łatwiej jest uchwycić świat tak, jak wcześniej udawało się to tylko mistrzom - $\mathrm{z}$ bliska.

Pozytywnym rezultatem wpływu nowych technologii jest, na przykład, palestyńsko-izraelska koprodukcja w reżyserii Emada Burnata i Guya Davidiego Pięć rozbitych kamer (2011). Palestyńczyk Emad, filmowiec-amator, za pomocą pięciu kamer dokumentuje różne oblicza walki mieszkańców jego wioski z izraelską agresją. Emad mieszka w Bil'in, na zachód od miasta Ramallah, na Zachodnim Brzegu. Pierwszą kamerą zarejestrował, jak izraelskie buldożery w 2005 roku najechały na wioskę i wyrwały z ziemi drzewka oliwne. W tym miejscu, wzdłuż ziemi należącej do jego znajomego, powstał wielki mur oddzielający żydowskie osiedla od Palestyńczyków. W pierwszych dniach oporu przeciwko żydowskim osadnikom i obecnym wszędzie żydowskim żołnierzom urodził się syn Mada - Gibreel. Emad dokumentował, jak chłopiec dojrzewał i stał się świadomym uczestnikiem pokojowych antyizraelskich protestów, a także jak szybko i silnie rozrastał się mur graniczny. Emand zarejestrował również, jak sympatycy z całego świata, również z Izraela, pomagali mieszkańcom wioski. Gdy opór się zwiększał i sytuacja stawała groźniejsza, zaczęły się aresztowania i masakra mieszkańców wioski. Autor Pięciu rozbitych kamer nie ma absolutnie żadnych doświadczeń w zawodzie filmowca. Jego film powstał dzięki rewolucji technologicznej, a jednocześnie można powiedzieć, że to historia niesamowicie czysta i osobista. Reżyser realizował wcześniej home movies. Dokumentował między innymi dorastanie swojego syna. Przystępując do realizacji Pięciu rozbitych kamer, zakładał od począt$\mathrm{ku}$, że będzie to film osobisty, robiony od środka, ponieważ relacje osób, które przyjeżdżały do wioski z zewnątrz, pozostawały bardzo powierzchowne.

Oczywiście, można byłoby dyskutować na temat samej historii ukazanej w Pięciu rozbitych kamerach: konflikt palestyńsko-izraelski, wojna, drastyczne ujęcia umierających ludzi. To tematy, którymi nasz współczesny świat jest przesycony. Istniało więc ryzyko, że i ten film będzie emocjonalnie szantażował widza. Emad, filmowiec-amator, kręci praktycznie wszystko, co się dzieje naokoło niego, nie trzymając się żadnych reguł filmowych. Jego reguła to instynkt. W jednej ze scen 
wyjaśnia powody kręcenia filmu. Widzimy w niej, jak izraelscy żołnierze aresztują jego brata. W kadrze jest również jego matka i ojciec, szarpiący się z żołnierzami. Sam autor nie potrafi przeciwstawić się sytuacji. Wyjaśnia, że jego bronią jest kamera. Przez jej wizjer widzi świat inaczej. Moje doświadczenie związane z realizacją filmu Self(less)-Portrait pozwala mi zrozumieć i współczuć autorowi.

Trend, w którym autor jest bohaterem, nasila się we współczesnym kinie dokumentalnym. Chęć zaistnienia jest coraz silniejsza, a możliwości coraz większe. W związku z tym wiele filmów, w których autor kieruje kamerę na siebie, rodzi się wyłącznie z potrzeby autoprezentacji lub autoterapii. Takim przykładem negatywnym z ostatnich lat jest - moim zdaniem - film A Complete History of My Sexual Failures (2008) Chrisa Waitta. Młody niezależny brytyjski filmowiec stara się odkryć, dlaczego wszystkie jego relacje z kobietami zakończyły się niepowodzeniem. Waitt kontaktuje się ze swoimi miłościami: począwszy od tej z czasów przedszkolnych aż po ostatnią i szuka odpowiedzi na nurtujące go pytania. Co więcej, w poszukiwaniu byłych partnerek pomaga mu jego matka. W pewnym momencie Waitt dowiaduje się, że głównym powodem miłosnych niepowodzeń są seksualne problemy autora-bohatera. Zaczyna więc wędrówkę po gabinetach lekarzy i psychologów. Wydaje się, że pomóc mogą mu tylko tabletki na potencję. Ich zażywanie prowadzi jednak do ostatecznej katastrofy.

Film Waitta nie jest próbą subtelnego przedstawienia intymnego problemu ani ukazania szerszego społecznego zjawiska, w ramach której widzowie mogliby identyfikować się z bohaterem. Trudno mi znaleźć inne określenie niż ekshibicjonizm. Od samego początku do końca konsekwentnie pozostaje wyłącznie jednopoziomową i prymitywną opowieścią o chłopaku nieudaczniku, nad którym powinniśmy się litować. W dodatku trudno pozbyć się wrażenia, że opowieść jest w dużej mierze wymyślona. Oczywiście Chris Waitt istnieje, możliwe, że spotkał w życiu tyle kobiet i być może, że wszystkie go zostawiły. Ale trudno mi się wczuć w tę historię, ponieważ autor nie wskazuje w żaden sposób, dlaczego chce ją opowiedzieć i dlaczego ma ona interesować widza. Po dziewięćdziesięciu minutach projekcji czuję się oszukany. Jednocześnie podaję w wątpliwość fakt, czy w ogóle oglądałem film dokumentalny. Dlaczego? Chodzi przede wszystkim o sposób jego realizacji. Częściowo był on kręcony przez samego autora, zazwyczaj są to sceny, w których sam siedzi przed kamerą i opowiada o swoich uczuciach. W scenach, w których odwiedza swoje dawne miłości, towarzyszy mu operator kamery, co powoduje, że wypowiedzi zazwyczaj są bardzo ogólne, nie dają możliwości emocjonalnej identyfikacji. Wszystkie informacje prezentuje wyłącznie za pomocą słów. Bezpośrednio z metodą realizacji powiązany jest również sposób montażu, na który twórca się zdecydował. Rozmowy często są montowane z użyciem kontrplanów. W efekcie często, kiedy Waitt prowadzi rozmowę z byłymi dziewczynami, wypowiedzi kobiet zostają przecięte ujęciami ukazującymi reakcję bohatera. Fałsz jest konsekwencją użycia dwóch kamer w tych scenach. 
Oczywiście ten sposób montażu jest często wykorzystywany w filmach dokumentalnych i przede wszystkim służy do tego, by uzyskać napięcie lub skrócić wywiad. Jednak trudno uniknąć wrażenia, że w przypadku filmu Waitta pojawia się on bez powodu. Ponadto wielokrotnie można podejrzewać, że przebitki na bohatera były dokręcane później. Zostaje efekt, który rozprasza i całkowicie odbiera historii wiarygodność.

Kolejny powód, dla którego widz może czuć się oszukany, to sztuczność wyczuwana w "grze” głównego bohatera. W scenie, w której decyduje się on na zażycie viagry, obserwujemy Waitta, jak w ciągu paru minut zjada całe opakowanie leku, ponieważ wydaje mu się, że jedna tabletka nie da właściwego efektu. Wydaje się, że powód, dla którego to robi, został wymyślony na potrzeby filmu. Bezpośrednio po niej następuje scena, w której Watt biega po Londynie i zaczepia kobiety z pytaniem, czy mogłyby natychmiast $z$ nim odbyć stosunek seksualny. Oczywiście bez efektu.

Po obejrzeniu filmu A Complete History of My Sexual Failures pozostało gorzkie przekonanie, że film autobiograficzny nie zawsze opowiada o czymś szlachetnym i osobistym, o kimś, kto mnie uprzejmie zaprasza do swojego domu i za co czuję do niego ogromny szacunek, ale może to być również film, $\mathrm{w}$ którym śmieję się nie $\mathrm{z}$ bohaterem, lecz z bohatera. Jest to uczucie, którego wolałbym unikać, oglądając filmy dokumentalne.

Rewolucja technologiczna pozwoliła podejść do bohatera najbliżej, czyli oddać sprzęt w jego ręce i całkowicie zniknąć z planu zdjęciowego. Kamery cyfrowe dzisiaj mają wmontowany mikrofon o dobrej jakości i są proste w obsłudze. Praktycznie wystarczy użyć jednego guzika, którym włączymy i wyłączymy nagrywanie. Nie trzeba się martwić ekspozycją, ładowaniem taśmy czy ostrością. O ostatecznym kształcie tego typu filmów decyduje jednak producent i montażysta. Głównym powodem podjęcia takich działań - poza dążeniem do osiągnięcia całkowitej autentyczności i szczerości - była chęć pokazania świata, do którego twórcy nie mieli wcześniej dostępu. W ten sposób dość często realizuje się filmy w miejscach objętych działaniami zbrojnymi. Za pierwsze takie dzieła uważane są Palestinian Diaries (1991) i Family Scenes Stonesand M16s (1991). A ich celem było przybliżenie widzom konfliktów pomiędzy Izraelem i Palestyną. Dwa lata później w Europie powstał Sarajevo Ground Zero (1993) o objętej wojną Jugosławii. Z czasem filmy takie zaczęto kręcić w związku z każdym większym konfliktem wojskowym. W Voices of Iraq (2004) producent Eric Manes zdecydował się ukazać Irakijczyków i sytuację w Iraku z innego niż telewizyjny punktu widzenia. Zależało mu na tym, żeby mieć historię z pierwszej ręki. By uzyskać zamierzony efekt, zdecydował się kupić tanio wiele używanych kamer cyfrowych i rozdał je Irakijczykom. Ich zadaniem było przez określony czas kręcić to, co działo się w ich życiu. Rezultatem jest film, w którym Irakijczycy swobodnie opowiadają o sobie, o marzeniach i nadziejach - o czymś, co nie było możliwe przez dwadzieścia cztery lata pod dyktaturą Saddama Husajna. Ten 
eksperyment pozwolił widzom wejść do świata, który był przez dwie dekady dobrze strzeżony, a nagle stał się nam bliski.

Tematy filmu autobiograficznego
Film dokumentalny, w którym autor zaznacza swoją obecność, istnieje niemal od początku kinematografii. Początkowo wyrażała się ona za pośrednictwem autorskich komentarzy opisujących wydarzenia na ekranie. Zdarzało się, że twórcy występowali przed kamerą w roli przewodnika. Autor jako temat filmu pojawił się znacznie później. Świadomość, że może on być kimś więcej niż tylko przewodnikiem, że może również być obiektem własnego filmu, zrodziła się dopiero w latach sześćdziesiątych. W tym czasie autobiograficzne filmy stały się częścią amerykańskiej i europejskiej awangardy filmowej.

Jednym z najważniejszych autorów realizujących autoportrety dokumentalne w Stanach Zjednoczonych jest filmowiec, artysta, pisarz i poeta pochodzący z Litwy Jonas Mekas. W 1949 roku wyemigrował do Stanów Zjednoczonych i osiadł w Nowym Jorku. Dwa tygodnie po przyjeździe kupił kamerę 16-milimetrową i zaczął nią nagrywać własne życie. I aż do dzisiaj nie przestał. Jego dziennik w sposób unikalny i nienachalny pokazuje życie człowieka. W słynnym stowarzyszeniu filmowym „Cinema 16" prowadzonym przez Amosa Vogela zetknął się z kinem awangardowym. Dziś uważany jest za jednego z najwybitniejszych przedstawicieli amerykańskiego filmu awangardowego. Film Diaries, Notes and Skatches (1949-1984) jest chronologicznie uporządkowanym zapisem 35 lat jego życia. Udało się w nim uchwycić atmosferę czasu, zarejestrować grupę najważniejszych artystów nowojorskich, jego rodzinę i kolegów. W przypadku jego twórczości trudno jednak mówić o pełnowymiarowych dokumentach. Są to raczej impresje, bliższe sztuce wideoartu niż filmowi. Wraz z Mekasem sławę jako twórcy filmów autobiograficznych zyskali Stan Brakhage i Carolee Schneemann. Ich filmom bliżej było jednak do poezji niż do klasycznej amerykańskiej szkoły dokumentalnej. Awangardziści skłaniali się raczej ku eksperymentowi.

Skierowanie kamery na siebie nastąpiło stosunkowo późno, co $\mathrm{w}$ dużej mierze było konsekwencją innego niż w Europie rozumienia filmu dokumentalnego w Stanach Zjednoczonych. Kojarzony był on przede wszystkim $\mathrm{z}$ badaniem nowych, obcych i egzotycznych terytoriów, grup społecznych, zjawisk, a nie eksplorowaniem własnej kultury. W latach 6o. XX wieku filmy autobiograficzne były uważane raczej za awangardowe niż za dokumentalne.

Za klasykę filmów autobiograficznych można dziś uznać film Marka Rance’a Death and the Singing Telegram (1983). Twórca, który jest reżyserem, operatorem i montażystą, przez pięć lat kręcił wydarzenia $\mathrm{w}$ jego rodzinie. Efektem końcowym jest intymny film opowiadający o egzystencji, o narodzinach i śmierci, o następstwie pokoleń. $Z$ kolei In Search of Our Fathers (1992) w reżyserii Marca Williamsa jest wzruszającym filmem, w którym reżyser ukazał swoją trwająca siedem lat podróż w poszukiwaniu biologicznego ojca. Williams wędruje po Sta- 
nach Zjednoczonych i po Francji, gdzie spotyka się z członkami rodziny, żeby dowiedzieć się czegoś o ojcu i o sobie. Film kończy się spotkaniem, podczas którego okazuje się, że ojciec nie wiedział, że ma syna. Za ojca współczesnego filmu autobiograficznego uznać można amerykańskiego reżysera Rossa McElwee'a, który w roku 1986 zrealizował Sherman's March: A Meditation on the Possibility of Romantic Love in the South During an Era of Nuclear Weapons Proliferation, w którym przedstawia fragment historii Ameryki przez pryzmat własnych relacji z kobietami.

Na początku XXI wieku, gdy kręcenie filmów autobiograficznych stało się znacznie łatwiejsze, wielu filmowców chwyciło za kamerę, by poprzez historie osobiste ukazać siebie jako przewodników po historii. Przykładem takie filmu jest głośny dokument Morgana Spurlocka Super Size me (2004). Amerykański niezależny filmowiec Spurlock decyduje się na eksperyment, w którym przez jeden miesiąc będzie jadł tylko jedzenie $z$ restauracji McDonald's. W filmie widać ogromny i zarazem negatywny wpływ fast food na życie psychiczne i fizyczne autora. Powodem, dla którego Spurlock zdecydował się na ten eksperyment, był problem coraz powszechniejszej otyłości w amerykańskim społeczeństwie. Większość klasycznych filmów autobiograficznych skupia się na drobnych historiach z życia, natomiast Spurlock koncentruje się na istotnym problemie społecznym. Eksponuje siebie, by zilustrować zjawisko, które dotyczy znacznej części społeczeństwa. Trudno określić, czy w związku z tym można Super Size Me uznać za film autobiograficzny, czy raczej za film, w którym autor przeprowadza widza przez pewną historię, używając siebie jako medium i bohatera. Choć trzeba dodać, że z dokumentu Spurlocka dowiadujemy się wiele o jego życiu prywatnym. Jego narzeczoną jest kobieta, która specjalizuje się w daniach kuchni wegańskiej i nie jest zbyt zadowolona $\mathrm{z}$ tego eksperymentu. Sam autor nie unika scen, w których cierpi z powodu jego skutków i pokazuje siebie w sytuacjach, które $\mathrm{z}$ powodzeniem można uznać za niesmaczne. Ale nie można uniknąć wrażenia, że wszystko to, co widzimy, jest tylko grą $\mathrm{z}$ widzem.

Za pioniera współczesnego filmu autobiograficznego uważam osobiście amerykańskiego reżysera dokumentalnego Rossa McElwee’a. Reżyser zasłynął filmami o własnej rodzinie i swoim życiu osobistym. Tematem jego filmów są zwykle jego relacje z ludźmi. Niewątpliwie pod wpływem direct cinema i cinéma vérité (autor był studentem $\mathrm{Ri}$ charda Leacocka), udało mu się stworzyć własny styl. McElwee zawsze pracował sam, co oznaczało, że był nie tylko reżyserem, bohaterem i narratorem, ale również operatorem kamery i operatorem dźwięku. Ten sposób realizacji pozwolił mu osiągnąć absolutną prywatność i otwartą relację z bohaterami, zwykle osobami mu bliskimi, z którymi ma dobry kontakt, znają się i mają do siebie zaufanie. Może sobie więc pozwolić na zadawanie pytań, na które nikt w obecności obcych ludzi nigdy nie otrzymał szczerej odpowiedzi. Własną metodę filmowania Rossa McElwee’a widać już w jego debiucie Charleen (1977), w którym

Medytacja Rossa McElwee'a 
przez jeden miesiąc śledził z kamerą swoją koleżankę, pisarkę Charleen Swansea. Jest to jego praca dyplomowa zrealizowana pod opieką Richarda Leacocka, więc czuć tu silny wpływ direct cinema. Film jest wyłącznie obserwacją życia pisarki i nie prezentuje jeszcze w pełni filmowego języka McElwee’a.

Styl reżysera objawił się po raz pierwszy w jego filmie Backyard (1984), który opowiada o jego rodzinie, ich domu w Karolinie Północnej i Afroamerykanach pracujących dla jego rodziny. W filmie, który jest również obserwacją, po raz pierwszy pojawia się bardzo osobisty komentarz reżysera. Zaczyna się od serii zdjęć, na których widzimy reżysera wraz z jego ojcem, a pod zdjęciami słychać komentarz McElwee’a:

Kiedy skończyłem studia, mój ojciec, który jest lekarzem i konserwatywnym republikaninem, zapytał mnie, co planuję robić w moim życiu. Powiedziałem mu, że interesuję się filmem, ale są też inne rzeczy, które mnie interesują, jak praca $\mathrm{z}$ black voter registration na południu, praca $\mathrm{w}$ misjach pokojowych albo możliwość wstąpienia do klasztoru buddyjskiego. Mój ojciec zastanowił się przez minutę nad tym, co usłyszał, i powiedział w końcu: „Synu, myślę, że twoja koncepcja kariery pozostaje niejasna, ale ja zdecydowałem, że nie będę się już więcej o ciebie martwił. Rezygnuję z wiary w ciebie". Nie do końca wiedziałem, jak odpowiedzieć ojcu, ale w końcu powiedziałem: „Dobra, tato! Wydaje mi się, że nie mam innej możliwości i muszę zaakceptować twoją rezygnację".

Ironia i gra, wyczuwalne w offie reżysera, stały się najbardziej wyrazistymi cechami McElwee’a, które rozwinął w najsłynniejszym filmie dokumentalnym Sherman's March, w którym reżyser jest niewątpliwie głównym bohaterem, poszukującym odpowiedzi na stawiane sobie pytania. Na samym początku opowiada on o celu, jaki mu przyświeca. Jego intencją było zrobienie filmu o generale Williamie Shermanie w ostatnich miesiącach wojny secesyjnej w Stanach Zjednoczonych. Reżyser był zafascynowany tragizmem i ironią, jakie niósł w sobie generał. Na Południu, które kochał, był znienawidzony za stosowaną przez jego wojsko taktykę „spalonej ziemi”, a na Północy, której nie lubił, został uznany za wielkiego bohatera. W trakcie wyjazdu McElwee’a z Bostonu, w którym w tym czasie mieszkał, wydarzyło się coś, co zmieniło jego życie i film o nim. Zostawiła go dziewczyna, co stało się dla niego traumatycznym przeżyciem. Nie wiedział, co ma dalej począć. Jedyne, co mu pozostało, to kamera, sprzęt dźwiękowy i dziewięć tysięcy dolarów, które dostał na zrealizowanie filmu, a przede wszystkim wielka miłość do kina.

W trwającym ponad dwie i pół godziny dokumencie autor tropi ślady Shermana, zatrzymując się w miastach, które odwiedzał generał, na polach bitew, które toczył. Koncentruje się jednak na kobietach, które generał odwiedzał lub przypadkowo spotykał. Przyznaje, że film ten to rozważania o romantycznej miłości na współczesnym Południu. Za czasy współczesne uważa wiek supermarketów, fast foodów, zimną wojnę i czasy, kiedy lekki sprzęt filmowy każdemu pozwoli kręcić film o swoim życiu. Film, który powstał w 1986 roku, 
jest jednocześnie świetnym obrazem lat osiemdziesiątych. McElwee tworzy nie tylko film historyczny i autobiograficzny, ale też pokazuje społeczeństwo współczesnych Stanów Zjednoczonych: działaczy społecznych i politycznych, fanatyków religijnych, kobiety marzące o sławie i karierze aktorskiej.

To, co jest naprawdę wielkie w filmie McElwee'a, to prostota pomysłu. Za fasadą filmu historycznego kryje się bardzo osobista historia reżysera o poszukaniu prawdziwej miłości. Oglądając film, widz uświadamia sobie, że postać reżysera i historyczna postać generała Shermana są do siebie bardzo podobne. Ironia i autodestrukcja autora-bohatera stają się metaforami stosunku do historycznego marszu generała. Momentami film wydaje się tylko pretekstem dla reżysera do znalezienia miłości, w związku z czym staje się on obrazem bardzo prywatnym i intymnym i w końcowym rozrachunku niewątpliwie szczerym. Reżyser przyznaje, że jego zamiarem było znalezienie miłości:

Naprawdę chciałem zrobić film o wojnie secesyjnej, ale miałem również świadomość, że film się skończy, jak tylko spotkam kobietę, którą pokocham. To byłoby zakończenie filmu. Ale szybko okazało się, że znalezienie miłości nie będzie takie proste. Oczywiście kamera ułatwiła mi kontakt z kobietami, ale z drugiej strony film był na tyle wyczerpujący, że nie byłem w stanie niczego konkretnego zrobić. Miałem kamerę w jednej ręce, mikrofon w drugiej i wielką maszynę do nagrywania dźwięku przymocowaną do paska. Nie było w takiej sytuacji łatwo podejść bliżej do kogokolwiek[7].

Poprzez pytania kierowane do napotkanych ludzi reżyser otwiera tematy, które dobrze zna, przygotował się wcześniej i wie, co przez ich przywołanie może osiągnąć. Jest to poniekąd konsekwencją doboru tematów, z którymi udało się zbudować bliską relację. Efektem jest film, który pokazuje prawdziwą twarz filmowanych osób, decydujących o spójności dzieła i opisujących świat autora-bohatera. Jako pewna znaczeniowa nadwyżka powstaje głęboki obraz współczesnego społeczeństwa amerykańskiego.

McElwee staje się bohaterem własnego filmu również za sprawą sposobu filmowania i montażu poszczególnych scen. Oczywiście przez większą część filmu bohatera nie widać, ponieważ kamerę umieścił na swym ramieniu. Mimo to jego obecność jest odczuwalna przez cały czas. Pierwszym elementem konstrukcji, który przypomina nam, że za kamerą stoi bohater, jest przesycony ironią komentarz[8], który przybliża widzowi świat wewnętrzny bohatera. Oprócz niego pojawiają się w filmie dwa razy odautorskie uwagi, które opisują ekranowe sytuacje. Ich geneza jest zaskakująca: reżyser zapomniał włączyć nagrywanie dźwięku, dlatego zdecydował, że pod niemy obraz nagra swój głos, który w sposób komiczny przedstawi treść rozmów.

[7] R. McElwee, cytat pochodzi ze strony internetowej: http://cinemadocumentaire.wordpress. com/2014/o3/18/documentary-film-an-interview-with-ross-mcelwee/ [dostęp: 20 września 2014].
[8] Oto fragment filmowego komentarza: „Mam wrażenie, że filmuję własne życie po to, by mieć życie do filmowania. Tak jak prymitywne organizmy, które odżywiają się, pożerając siebie, powiększają się, ponieważ się zmniejszają". 
Kolejnym elementem, który pozwala nam pamiętać o obecności bohatera, są wkradające się w kadr części jego ciała. W scenie, kiedy reżyser podróżuje samochodem razem z Pat, dziewczyną, która marzy o karierze aktorskiej, partnerka zaczyna mu czytać przyszłość z ręki. W kadrze pojawiają się dwie trzymające się dłonie. O obecności autora przypomina więc fizyczny kontakt reżysera $\mathrm{z}$ bohaterami. Kiedy przypadkowo spotyka koleżankę z dzieciństwa, obejmują się. Reżyser traci na moment kontrolę nad kamerą, ale specjalnie jej nie wyłącza, nawet kiedy w obrazie widać nieostry sufit. Dzięki temu ujęciu jesteśmy bliżej bohatera, możemy zrozumieć jego uczucia i relację z osobą, która w tym momencie spotkał.

W filmie pojawiają się również sceny, w których reżyser sam występuje przed kamerą. Zazwyczaj w nocy, kiedy inni śpią, zastanawia się nad sensem tego, co robi. Czy nie powinien się skupić na filmie o samym generale Shermanie? Czasami używa monologu, żeby wyjaśnić, co się dzieje się w innym miejscu, a czego nie może sfilmować. W jednej ze scen reżyser śpi na drzewie i opowiada, że kobieta, u której spędził poprzednią noc, ma już romans z innym mężczyzną, i dlatego on znalazł się na drzewie, a nie z nią w łóżku.

McElwee rozwija swój unikatowy styl w kolejnych filmach autobiograficznych, jak Time Indefinite (1993), Six O'clock News (1997) i Bright Leaves (2003). Jego twórczość stała się inspiracją dla wielu innych dokumentalistów, którzy zdecydowali się na filmy autobiograficzne. Warto pamiętać, że jego filmy są nie tylko skromnymi opowieściami, prywatnymi i wzruszającymi. To wielopoziomowe, inteligentne, pełne humoru utwory z silną strukturą narracyjną, które są również istotnymi wypowiedziami z zakresu socjologii i historii.

Narracja w cieniu sensacji
Od niepamiętnych czasów towarzyszyła ludzkości chęć dokumentowania i potrzeba pozostawienia następnym pokoleniom śladów tego, co się wydarzyło. Nasi przodkowie malowali na ścianach jaskiń. $\mathrm{Z}$ tego samego powodu powstała znaczna część literatury, malarstwa czy rzeźby. Słowo „dokument” pochodzi od łacińskiego „documentum” i oznacza zapis historyczny, świadectwo lub dowód. Przymiotnik „dokumentalny” oznacza więc coś, co jest prawdziwe, co można udowodnić, co ma udokumentowane podłoże.

W obiegowej opinii pojęcia „film dokumentalny” jako pierwszy użył szkocki reżyser John Grierson, który definiował ten rodzaj filmu jako „twórcze przetworzenie rzeczywistości”. Dokument przedstawia „rzeczywisty” świat oczyma twórcy, z jego punktu widzenia. Tak jak każda forma sztuki, tak i dokument przeszedł ewolucję, podczas której poza ambitnymi filmami artystycznymi powstało również wiele filmów edukacyjnych i propagandowych. Dzisiaj za film dokumentalny uważa się najczęściej utwór, który opowiada o czymś nowym, odkrywa przed widzem nowe tematy, przybliża Innego. Film ma za zadanie przenieść nas w świat, którego sami nie moglibyśmy odkryć. Powinien więc otwierać widzowi oczy, stawać się zaczynem dyskusji zarówno w sferze 
społecznej, jak i politycznej. W konsekwencji filmowcy często opierają swoje dzieła na ciekawym bohaterze albo na ciekawym wydarzeniu, ale starają się ukryć swój stosunek do poruszanego tematu. Od dłuższego czasu towarzyszy mi wrażenie, że to, co widzę na ekranie, mógłbym przeczytać w gazecie lub zobaczyć w dziesięciominutowym reportażu telewizyjnym. Twórcy często starają się możliwie ograniczać ingerencję, niekiedy szokować samym doborem tematu. Boom na kino dokumentalne sprzyja sytuacji, w której tego typu dokumenty trafiają za sprawą dystrybucji kinowej do szerszej widowni. Bardzo często autor i producent na siłę wydłużają metraż filmu tylko po to, by zmieścić się w wymaganiach stawianych przez kina. Jeżeli uznajemy film dokumentalny za wypowiedź twórczą, autorską, za utwór artystyczny, a nie tylko rozbudowany komunikat informacyjno-propagandowy czy komercyjny, musimy myśleć przede wszystkim o tym, jak w ciekawy sposób opowiedzieć temat. Bohater lub wydarzenie powinny być tylko punktem wyjścia, a nie samym w sobie środkiem do celu.

Na czym właściwie polega dobre kino? Według mnie film jest dobry dopiero wtedy, kiedy wywołuje w widzu emocje, gdy po wyjściu $\mathrm{z}$ kina zachwycam się albo, wręcz przeciwnie, nie zgadzam się z bohaterem. Jest prawdziwym filmem, kiedy zmusza do dyskusji, skłania do refleksji. W dziele Petera Friedmana i Toma Joslina Silverlake Life: The View from Here, obserwując miłość dwóch mężczyzn, wchodzimy w rzeczywistość głęboko stabuizowaną: problem homoseksualizmu i związane z nim zagadnienie AIDS. Widz ma okazję zobaczyć inny punkt widzenia zjawisk, które przez kulturę masową i środki masowego przekazu są zwykle negatywnie wartościowane. Film ten nie ma walorów kina edukacyjnego czy politycznego. W efekcie końcowym odnosi się wrażenie, że nie mamy do czynienia $z$ filmem o homoseksualizmie czy ciężkiej chorobie, lecz z uniwersalnym utworem o miłości. Jego siła polega na szczerości, z jaką bohaterowie odkrywają swoje życie przed widzami.

McElwee otwiera Sherman's March komentarzem, w którym opowiada widzom, że został odrzucony przez kobietę. Rozpoczyna swoją podróż w poszukiwaniu idealnej miłości. Łatwo sobie wyobrazić, że będzie opowiadał o kolejno spotykanych kobietach, mniej lub bardziej interesujących. Twórca jednak nie zatrzymuje się na poziomie frustrującego go problemu, ale zaprasza widza w świat, w którym pokazuje swoimi oczami współczesne Stany Zjednoczone. Konstrukcja Sherman's March od początku jest bardzo klarowna: widz śledzi dwie odrębne opowieści - o generale Shermanie i o sfrustrowanym reżyserze, którzy, jak się późnej okazuje, są do siebie bardzo podobni.

W filmie fabularnym przed zdjęciami powstaje scenariusz, który oprócz ciekawej historii zawiera mocną strukturę dramaturgiczną i narracyjną. Filmy autobiograficzne często są jej pozbawione, ponieważ kieruje nimi życie. By zrobić film, by opowieść była spójna, reżyser musi mieć coś mocnego i ważnego do powiedzenia. Film dokumentalny nie powstaje wyłącznie na bazie gotowego scenariusza. $Z$ założenia kieruje 
nim prawdziwe życie. Reżyser-dokumentalista może wprawdzie przewidywać różne sytuacje w biografii bohatera, co pozwala mu przygotować się do realizacji. Może również popychać bohatera w założonym kierunku, bo wie, że to będzie ważne dla opowiadania. Zrealizowanie zamkniętego, napisanego przed zdjęciami scenariusza jest w dokumencie po prostu niewykonalne, choć dokumentalista jest również filmowcem, nie może zapominać o fakcie, że historia w filmie musi się opowiadać i musi zawierać takie elementy jak struktura, konflikt, montaż, rozwój bohatera. O tym, czym się różni narracja w filmie dokumentalnym od filmu fabularnego, rozmawiałem z Pawłem Łozińskim, który odwołał się do tradycji i historii filmu dokumentalnego:

Krzysztof Kieślowski mówił, że narracja w filmie dokumentalnym polega dla niego bardziej na rozwoju pewnej autorskiej myśli niż na rozwoju wydarzeń. Tak kiedyś rzeczywiście było, chociaż jego film dokumentalny Pierwsza miłość przeczy tej definicji. Filmy dokumentalne były krótkie, 10-20-minutowe, funkcjonowały w kinie jako dodatki przed filmem fabularnym. Krótka forma oznaczała, że trzeba pomieścić w niej maksymalnie dużo treści, myśli. Stąd były to często filmy metaforyczne, opowiadające przez „częśćc o jakiejś całości. Technika była toporna, ekipa filmowa duża. To również wymuszało określony sposób myślenia i opowiadania. Takie to były czasy.

Po czym Paweł Łoziński wraca do współczesności:

Teraz się to wszystko bardzo zmieniło. Film dokumentalny ma swoje miejsce praktycznie tylko w telewizji. W technice filmowej nastąpił niewyobrażalny rozwój. Dziś każdy ma w kieszeni, w swoim telefonie, narzędzie do robienia filmów. Operator może wejść z maleńką kamerą praktycznie wszędzie. Możemy dojść maksymalnie blisko bohaterów, intymnie ich obserwować. Nakręcić sceny o sile emocji i prawdy kiedyś nieosiągalnej. To wszystko sprawiło, że zmienił się też sposób opowiadania, narracji w filmie dokumentalnym. Można zarejestrować prawie wszystko, być prawie w każdej sytuacji, więc siłą rzeczy opowiadamy przez rozwój wypadków. Bardzo często zdarza mi się iść przy kręceniu dokumentów bardzo „fabularnie” za rozwojem wypadków. Siedzieć z kamerą i patrzeć, co się dzieje u bohaterów. Nie mamy tak łatwo jak fabularzyści. Nie piszemy dialogów, nie zatrudniamy aktorów. To, co chcemy uzyskać, musimy „wycisnąc', czasem sprowokować albo zwyczajnie wyczekać. Nie jesteśmy też tak precyzyjni $\mathrm{w}$ opowiadaniu. W montażowni tworzymy punkty zwrotne i kulminacje, które normalnie zapisane są przez fabularzystów w scenariuszu. Ale w zamian dostajemy rzeczy nieprzewidziane, bardzo prawdziwe, czasem niemożliwe do wymyślenia w fabule. Coś za coś.

Według Pawła Łozińskiego narracja w dokumencie powstaje częściej przypadkowo i jeżeli reżyser chce ją mieć, musi po prostu uzbroić się w cierpliwość, która jest niewątpliwie najważniejszą cechą każdego dokumentalisty. Inny punkt widzenia reprezentuje Jacek Bławut:

Zawsze robię swoje filmy dokumentalne z konstrukcją bardzo fabularną. $\mathrm{Z}$ reguły to są tematy dosyć trudne i żeby kogoś zatrzymać przy takim opowiadaniu, trzeba mieć taką konstrukcję, która wciągnie widza. Kiedy 
kręciłem Nienormalnych, miałem scenariusz, na którym oparłem film. Oczywiście powstało masę niezaplanowanych scen. $\mathrm{W}$ dokumencie trudno przewidzieć niektóre sytuacje. Na przykład jeden z bohaterów mi powiedział, że on w takiej scenie nie wystąpi. Coś, co jest niemożliwe w filmie fabularnym, gdzie są wszyscy profesjonalistami i zazwyczaj dobrze zapłaceni. Ale na tym polega czar filmu dokumentalnym, trzeba być czujnym.

Dla Bławuta film dokumentalny powstaje właściwie dopiero w montażu. Znaczenie montażu podkreśla również, choć w zupełnie innym kontekście, Paweł Łoziński:

Później, na etapie montażu, pojawia się największa różnica w narracji pomiędzy fabułą i dokumentem. W fabule masz na tym etapie mniejszą możliwość tworzenia. Ogranicza cię chronologia, kostium czy fryzura aktora. W dokumencie możesz spokojnie zamienić pierwszą scenę z ostatnią. Trochę to jest jak z miłością, nigdy nie wiesz, czy najważniejsza była ta pierwsza, czy ostatnia.

Oczywiście, film to nie matematyka, ale nie można zapominać, że obowiązują jednak pewne zasady dotyczące konstrukcji. Każdy pełnometrażowy film fabularny, skierowany do szerokiej widowni, trzyma się pewnych reguł. Czy dokumentalista również trzymać się reguł? Czy mimo wszystko nie jest jednak najważniejsza prawda o bohaterze? Albo - czy reżyser ma prawo kierować bohaterem na etapie zdjęć lub montażu, by osiągnął założony efekt? Uważam, że każdy reżyser-dokumentalista musi to mieć na uwadze. Nie znaczy to, że ma się kierować wyłącznie zasadami narracji i dramaturgii, bo obawiam się, że mogłoby to naruszyć ducha filmu dokumentalnego. W autobiografiach dokumentalnych sytuacja przedstawia się nieco inaczej. Wydaje się, że autor-bohater ma w nich całkowitą kontrolę nad wydarzeniami, ponieważ sam wprowadza nas w swój świat, a pokazuje nam to, co chce pokazać. Można powiedzieć, że jest aktorem we własnym filmie.

Podczas gdy autorzy direct cinema tworzyli strukturę i narrację swych filmów na stole montażowym, twórcy cinéma vérité kierowali swoimi bohaterami już w trakcie zdjęć. Autorzy filmów autobiograficznych mają z pozoru pełną możliwość kontroli nad filmowaną materią. Powraca pytanie, które ponad pięćdziesiąt lat temu zadawali sobie również Richard Leacock, bracia Maysles czy Robert Drew: czy w takim razie to nadal jest film dokumentalny? Moje stanowisko jest takie: esencją filmu dokumentalnego są tematy, które wypływają z wnętrza, z wewnętrznej potrzeby twórców.

Tym, co pozwala odróżnić autobiograficzny film dokumentalny od zwykłego home video, jest narracja. Sam fakt, że autor bierze do ręki kamerę i kręci ciekawe momenty ze swojego życia, nie decyduje o tym, że powstanie film. Zapis z wakacji nad morzem czy świąt Bożego Narodzenia to nie jest jeszcze film dokumentalny. Uważam, że staje się filmem dopiero na etapie montażu, szczególnie w przypadku filmów dokumentalnych. Trudno sobie wyobrazić, że szeroka publiczność zainteresuje się po prostu zarejestrowanym pobytem zupełnie obcej rodziny

Film autobiograficzny na granicy home video 
podczas wakacji nad morzem. Dopiero sposób, w jaki przedstawiamy świat bohatera i poprowadzimy go do celu, może przemienić home video w prawdziwy film. Przykładem takiej sytuacji jest przywoływany już film Pięć rozbitych kamer. W zasadzie jest on pozbawiony struktury narracyjnej. Naturalną narracją w filmie staje się bieg wypadków czas, który odsłania przed nami wzmagający się konflikt. Sądzę, że warto jeszcze raz powrócić do okoliczności, w jakich film powstawał. W roku 2005 Emad zaczął realizować materiały dokumentalne wyłącznie na wewnętrzne potrzeby protestujących. Z czasem jednak część filmów wyciekła na zewnątrz, stając się dowodem w izraelskim sądzie. Zostały też zamieszczone na YouTube w celu zwiększenia liczby protestujących. Kiedy media zaczęły się bardziej interesować konfliktem, materiały Emada stały się częścią newsów w lokalnych i zagranicznych stacjach. W tym czasie Emad podjął pracę jako operator dla różnych telewizji. W 2009 roku skontaktował się z nim izraelski reżyser Guy Davidi i zaproponował mu współpracę, której rezultatem miał być film dokumentalny. Większość materiałów powstała więc, zanim zrodziła się idea filmu. By zachować autentyczność, Davidi nie brał udziału w zdjęciach, choć wówczas realizacja została już podporządkowana bardziej konkretnemu planowi. Davidi uznał, że Emad ma być bohaterem filmu, opowiadającym historię z punktu widzenia operatora. Zaproponował również, by historię budować wokół opowieści o kamerach Palestyńczyka. Dodatkowo chciał wykorzystać amatorskie materiały, które Emad kręcił w domu z jego rodziną. W roku 2009 powstał więc zalążek filmu, który premierę miał trzy lata później. Davidi dołączył off i opracował strukturę filmu. W 2011 twrócy nawiązali współpracę z francuską montażystką Veronique Lagoarde-Segot i ona dołączyła do projektu.

Narracja wymyślona właściwie ex post oparta została na kilku chwytach. Davidi zdecydował, że jej osią będą relacje w rodzinie Emada oraz konflikt zbrojny. Film rozpoczyna się narodzinami syna, który w chwili zamknięcia zdjęć ma 6 lat. Chłopak jest do pewnego momentu przewodnikiem, jednak z czasem jego postać staje się niewyraźna i gubi się wśród mocnych, emocjonalnych scen. Wydaje się, że podstawę konstrukcji będą stanowiły historie pięciu kamer. Są one rozbijane przez żołnierzy izraelskich przypadkowo, zdarzenia te nie mogą więc stanowić klucza do wydzielenia kolejnych etapów opowieści. Rozchwianie narracji wynika $\mathrm{z}$ faktu, że reżyser jest amatorem, który, jak sam mówi, kręci wszystko, co widzi. Paradoksalnie jednak, amatorskość i związana z nią autentyczność filmu jest jego główną siłą. Bez współpracy Emada i Davidi z pewnością nie powstałby film wybitny. Gdyby nie serce i chęć opowiedzenia o swoich emocjach przez Emada, widz nigdy nie miałby okazji spojrzeć $\mathrm{z}$ bliska na tę historię. Natomiast bez udziału Davidiego $\mathrm{w}$ projekcie powstałoby pewnie nic więcej niż home video.

Struktura, konflikt, przemiana bohatera czy montaż - to elementy, które tworzą filmową narrację. Film to sztuka, reżyser to artysta, a trzymanie się ściśle reguł wpływa niekorzystnie na dzieło. Tak jak 


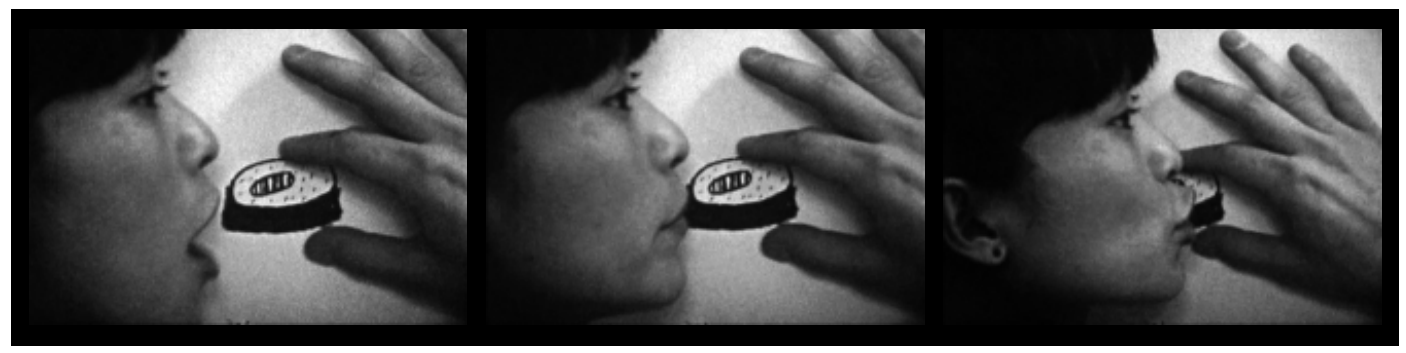

każde inne dzieło sztuki, należy go tworzyć zgodnie z głosem serca, nie według schematu. W filmie trzeba przede wszystkim czuć oddech człowieka, czuć, że w jego żyłach płynie krew.

Przyglądając się moim etiudom szkolnym, które powstały w czasie studiów w łódzkiej szkole filmowej, nie miałbym odwagi wskazać wszystkich elementów struktury narracyjnej, o których pisałem. Skłamałbym, gdybym powiedział, że każdy mój film dokumentalny był od początku do końca dobrze przemyślany. Byłoby kłamstwem stwierdzenie, że powstały one z mojej osobistej potrzeby, że wyniknęły $z$ potrzeby poruszenia danego tematu. Niemal zawsze prawdziwe myślenie o strukturze i narracji zaczynało się dopiero na etapie montażu. Przykładem jest mój film dyplomowy Self(less)-Portrait. Kręciłem go przez dwanaście miesięcy. Na samym początku umiałem odpowiedzieć sobie tylko na pytanie, po co ten film robię, ale zupełnie nie byłem świadom, do czego proces realizacji doprowadzi. Nie wiedziałem, czym się skończy, a nawet jaką sceną go rozpocznę. Stopniowo coraz bardziej byłem świadom, które wątki śledzić, a które zostawić. Kiedy po roku powiedziałem, że już wystarczy, czułem, że mam to, czego potrzebuję, i zacząłem montować film. Dopiero na tym etapie stworzyłem konstrukcję, którą widać. Montaż zajął mi prawie cały kolejny rok i muszę przyznać, że to było jedno z moich najciekawszych doświadczeń filmowych. Pierwotny zamysł zakładał współpracę z profesjonalnym montażystą, ale najpierw chciałem sam obejrzeć trzydzieści godzin materiałów. Kiedy miałem wybranych pięć godzin i przyszedł czas na zaproszenie montażysty do projektu, uświadomiłem sobie, że na tyle polubiłem to ustawianie pojedynczych scen w sensowną całość, że nie chcę pomocy drugiej osoby. Uświadomiłem też sobie pewną trudność, która towarzyszyła mi również później, podczas pierwszych pokazów filmu: nie wyobrażałem sobie, żebym mógł się z kimkolwiek podzielić tak osobistymi materiałami.

Teraz, kiedy mam przed sobą kolejny projekt filmu dokumentalnego, przyznaję, że staram się bardziej myśleć o strukturze i sposobie narracji już przed rozpoczęciem zdjęć. Wewnątrz mnie wciąż toczy się walka pomiędzy dbałością o strukturę i zasady konstrukcyjne a zachowaniem tego, co czuję, co podpowiada intuicja. W jednym z najładniejszych momentów filmu Shermana Mach pewna bohaterka mówi do reżysera: „Możesz wyłączyć kamerę? To jest bardzo ważne. To nie jest sztuka, to jest życie!”. A chyba przecież o to dokumentalistom chodzi.
Kadry z filmu dokumentalnego Self(less) Portrait, reż. Matej Bobrik, prod. PWSFTviT w Łodzi, 2012 

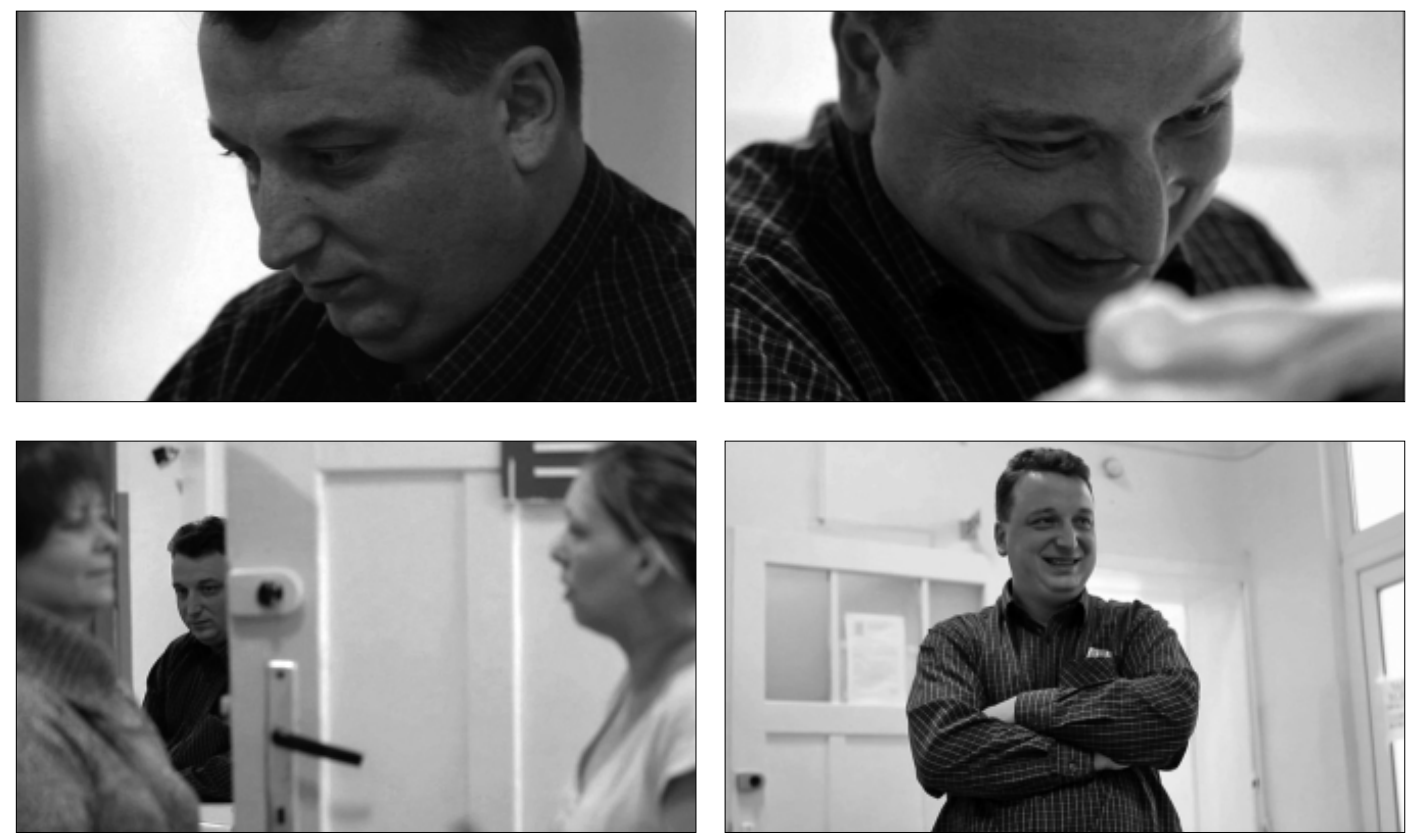

Birth, dir. Karol Starnowski (Łódź from Dawn till Dusk), prod. Polish National Film School in Lodz, 2011 